\title{
The oldest brachymetopid trilobite record from the European peri-Gondwana
}

\author{
Sofia Pereira, Carlos Marques da Silva, Miguel Pires \& Artur Abreu Sá
}

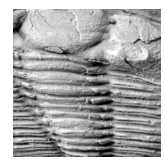

Radnoria guyi sp. nov. from the middle Berounian (upper Sandbian/lower Katian, Upper Ordovician) of the Cabeço do Peão Formation, Central Portugal is the best preserved and most completely known Ordovician species of the genus, and the stratigraphically earliest known from European peri-Gondwana. Until now, the oldest record of the genus was from the upper Sandbian?/lower Katian of South China. The new Portuguese record sheds new light on our understanding of the biogeography of Radnoria, suggesting the possibility of a southern high-latitude Gondwanan origin for the genus. - Key words: Radnoria, Aulacopleurida, Queixopêrra Member, Upper Ordovician, Portugal.

Pereira, S., MARques DA Silva, C., PIRES, M. \& SÁ, A.A. 2015. The oldest brachymetopid trilobite record from the European peri-Gondwana. Bulletin of Geosciences 90(3), 543-553 (4 figures). Czech Geological Survey, Prague. ISSN 1214-1119. Manuscript received September 5, 2014; accepted in revised form March 5, 2015; published online May 12, 2015; issued September 30, 2015.

Sofia Pereira (corresponding author) \& Carlos Marques da Silva, Departamento de Geologia e Instituto Dom Luiz, Faculdade de Ciências, Universidade de Lisboa, 1749-016 Lisboa, Portugal; ardi_eu@hotmail.com, paleo.carlos@fc.ul.pt • Miguel Pires, Arcodere, Unipessoal Lda., Rua da Sociedade 2, 2350-030 Torres Novas, Portugal; arcodere@gmail.com • Artur Abreu Sá, Departamento de Geologia, Universidade de Trás-os-Montes e Alto Douro, Quinta de Prados, 5000-801 Vila Real, Portugal; asa@ utad.pt

The trilobite family Brachymetopidae Prantl \& Přibyl, 1951 is represented in the Ordovician and Silurian exclusively by Radnoria Owens \& Thomas, 1975. Until this paper, the only lower Katian (Upper Ordovician) record of the genus, the oldest reported, was that of $R$. dolicocephala (Ji, 1986) from South China. Radnoria is uncommon in Ordovician rocks throughout the world but is particularly diverse in the Upper Ordovician of the European peri-Gondwana, with three Katian species, $R$. carlsi Owens \& Hammann, 1990, R. loredensis (Thadeu, 1947) and $R$. simplex (Kolobova, 1978), the last originally described from Uzbekistan. Based on the stratigraphical and palaeogeographical occurences of Radnoria, as well as on the distribution patterns of other trilobite genera, Hammann (1992) suggested a probable Laurentian origin for Radnoria and until now this view has not been challenged.

In Portugal, Radnoria was known from only three specimens assigned to $R$. loredensis, discovered by Nery Delgado in October 1871 in the upper Berounian/Kralodvorian? (Ka2-Ka3 stage slices) beds of the Porto de Santa Anna Formation, in the Buçaco region, and later figured by Thadeu (1947, pl. 2, figs 11-13) and Young (1985, pl. 49, figs 12-14). We here report a new species, Radnoria guyi, from the Queixopêrra Member (middle Berounian, approximately Sa2/Ka 1 stage slices) of the Cabeço do Peão Formation in the Mação region (Figs 1, 2). Palaeontological study of the Queixoperrra Member began over one hundred years ago, in August 1902, with a geological campaign commissioned by Nery Delgado. During the last five decades these beds have been frequently sampled by both palaeontologists and fossil collectors (see Sá et al. 2011 and references therein) but no specimens of Radnoria have previously been reported.

\section{Geographical and geological settings}

The specimens of Radnoria guyi sp. nov. came from a classical outcrop of the Queixopêrra Member of the Cabeço do Peão Formation near the village of Pereiro, located $4 \mathrm{~km}$ NW of Mação township in the northern part of the Santarém District, central Portugal (Fig. 1). Ordovician rocks in the Mação region crop out in the Amêndoa-Mação Syncline, which lies in the southwestern portion of the Central Iberian Zone (CIZ; Fig. 2A). This syncline comprises two lithostratigraphic sequences separated by a high angle unconformity: the Beiras Group, a monotonous, kilometre-thick series of intercalated shales and greywackes of Neoproterozoic to middle (?) Cambrian age; and the post-Cambrian Palaeozoic metasedimentary sequence, 


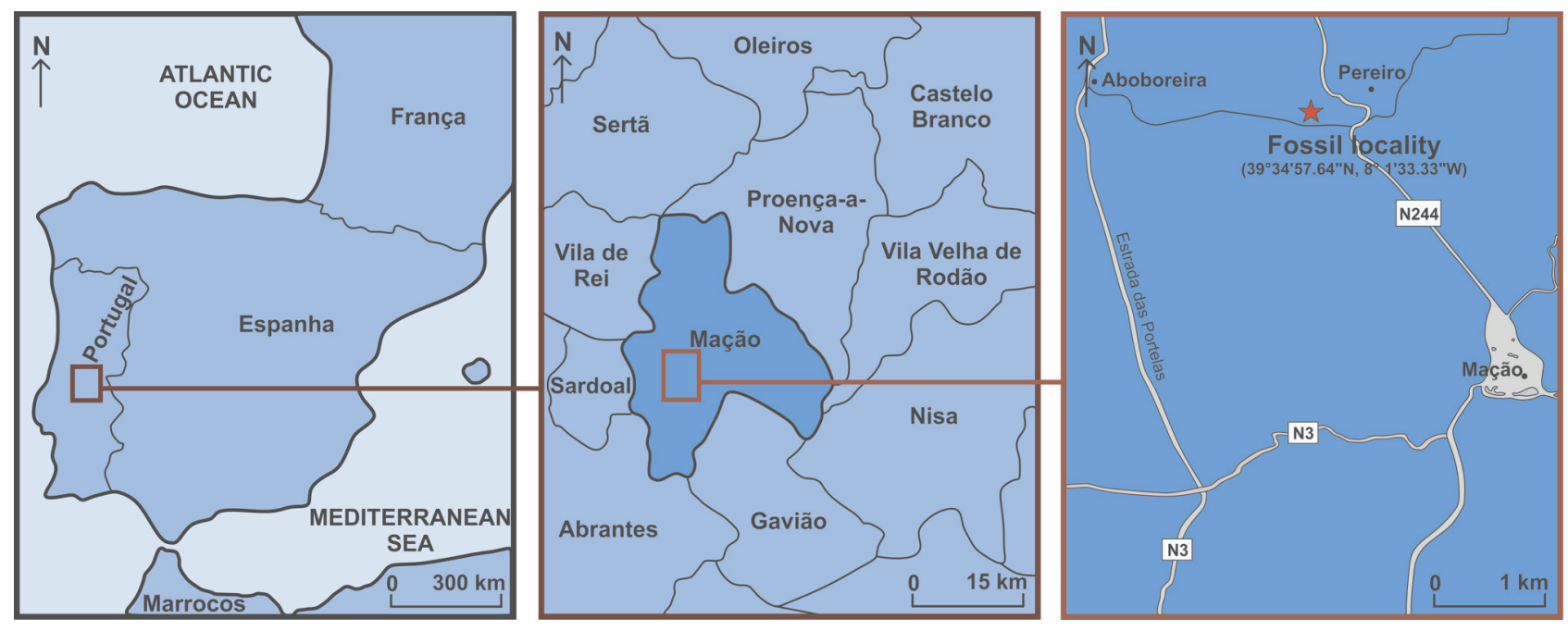

Figure 1. Geographic location of the classic outcrop of the Queixopêrra Member of the Cabeço do Peão Formation near Pereiro village, Mação (central Portugal).

ranging in age from Early Ordovician to Early Devonian (Romão 2000).

The Cabeço do Peão Formation (80-110 m thick) was defined by Young $(1985,1988)$ in the Dornes region (central Portugal) and is correlated with the upper Sandbian to lower Katian stages (Sa2-Ka1 stage slices; Paris in Romão 2000). This unit has an erosive contact with the underlying upper Darriwilian to lower Sandbian Ribeira do Casalinho Formation (sensu Romão 2000). The base of the Cabeço do Peão Formation is marked by a thin oolitic ironstone layer, the Favaçal Bed of late Sandbian age (Sa2 stage slice; Romão 2000), which correlates with an extensive Upper Ordovician ironstone bed occurring in Southern and Central Europe and North Africa (e.g. the Zdice-Nučice Bed in Bohemia), and is related to the Sardic unconformity (sensu Hammann \& Leone 1997). The lower part of the Cabeço do Peão Formation above the Favaçal bed is composed of bioturbated and highly fossiliferous micaceous mudstones (Queixopêrra Member), changing upwards to bioturbated silty sandstones (Aziral Member) and, finally, to coarser sandstones, occasionally conglomeratic at the top (Serra do Cadaveira Member, Young 1988, Romão 2000; Fig. 2B). The Cabeço do Peão Formation is interpreted as a terrigenous regressive sequence that is bounded at the base and top by sedimentary hiatuses representing marine transgressive events. The Cabeço do Peão Formation crops out in central Portugal in the Fajão, Moradal, Dornes, Amêndoa, Mação, Penha Garcia and, possibly, Portalegre regions (Delgado 1908; Cooper 1980; Young 1985, 1988; Piçarra et al. 1999; Sequeira et al. 1999; Romão 2000; Metodiev \& Romão 2008; Metodiev et al. 2010). It is the lateral equivalent of the Louredo Formation in the Buçaco Syncline (central Portugal) and of the Chão do Amieiral Formation, in the Trás-os-Montes region of northern Portugal (Sá 2005, Sá et al. 2005).
The Queixopêrra Member is highly fossiliferous, rich in trilobites, brachiopods, bryozoans and echinoderms; its fossil assemblages have been studied for over a century (Delgado 1908; Cooper 1980; Young 1985, 1988; Romano 1980, 1982, 1991; Romano \& Henry 1982; Romão et al. 1995; Romão 2000; Bruton 2008; Guy \& Lebrun 2010; Vaz 2010; Pereira et al. in press). Palaeontological data reported in previous works (see Sá et al. 2011) indicates a middle Berounian age (approximately $\mathrm{Sa} 2 / \mathrm{Ka} 1$ stage slices in the global chronostratigraphic chart).

At the outcrop studied, the Queixopêrra Member is approximately $35 \mathrm{~m}$ thick and comprises several fossiliferous beds. Trilobite assemblages vary throughout the sequence, the most diverse ones occurring in the lower part of the member where odontopleurids and calymenids are dominant. The middle and upper portions of the member are richer in illaenids, with some odontopleurids and cheirurids also present. The specimens of Radnoria guyi sp. nov. originate from the middle and upper parts of the Queixopęrra Member (Fig. 2B), from beds that yielded a moderately diverse trilobite assemblage with Actinopeltis, Colpocoryphe, Dalmanitina, Eoharpes, Panderia, and Prionocheilus.

\section{Taphonomical and palaeoecological remarks}

The Upper Ordovician sequences in the Central Iberian Zone in Portugal were deposited in a series of topographic basins and rises and basin that were especially marked during Katian times. The region of present day DornesAmêndoa-Mação was interpreted as a topographic high by Young (1985).

The fossil assemblage of the Queixopêrra Member may 


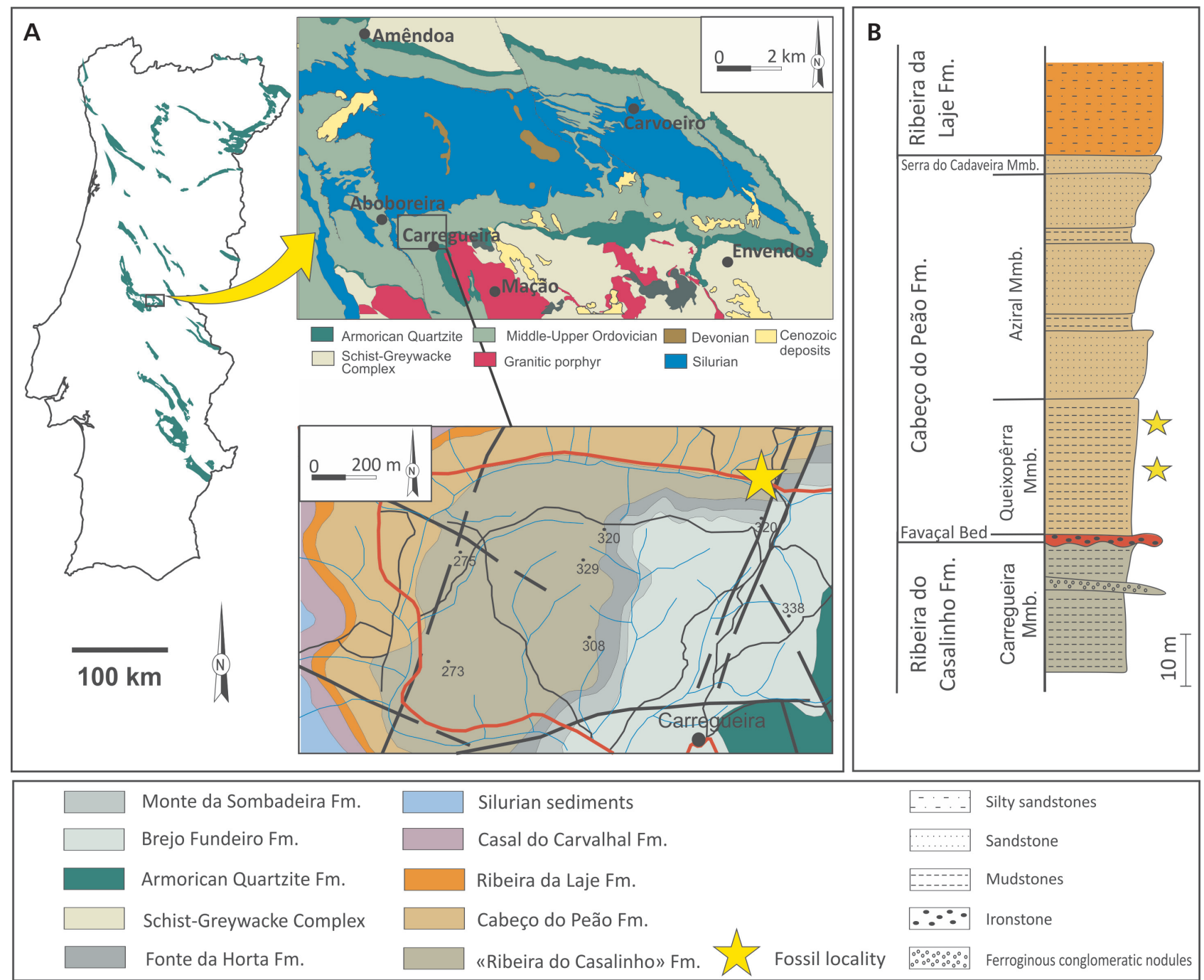

Figure 2. A-geological sketch map showing outcrops of Ordovician rocks in Portugal and details of the Amêndoa-Mação Syncline with the position of the fossil locality. • B - schematic lithostratigraphic column (adapted from Romão 2000).

be characterized taphonomically as a mixed orictocenosis, with both autochthonous and sub-autochthonous elements. This orictocenosis was formed as the result of a rapid change in environmental conditions, with episodes of rapid burial that were often fatal to the partly suspension-feeding fauna. These conditions are similar to those suggested for the Upper Ordovician orictocenosis of Sardinia (Conti \& Serpagli 1988, Leone et al. 1991). Romão (2000) interpreted the Queixopêrra Member as resulting from deposition in confined depressions formed during periods of regression (Le Corre et al. 1991).

The trilobite assemblages of the Queixopêrra Member, particularly of the middle section, bear some resemblance to the illaenid-cheirurid assemblage of Fortey (1975), common in Ordovician carbonate build-up environments (Mikulic 1981, Zhou et al. 1989, Carlucci \& Westrop 2012).

\section{Systematic palaeontology}

Order Aulacopleurida Adrain, 2011

Family Brachymetopidae Prantl \& Přibyl, 1951

\section{Genus Radnoria Owens \& Thomas, 1975}

Type species. - Radnoria syrphetodes Owens \& Thomas, 1975; from the Dolyhir Limestone, Wenlock Series, Wales, UK.

Other species. - Information is given in the following order: species name and author; original generic assignment (when different); rock unit (lithostratigraphic or other), age, geographical occurrence.

Radnoria bretti Adrain \& Tetreault, 2005; Rochester Formation, Wenlock, New York, USA. 
Radnoria carlsi Owens \& Hammann, 1990; Cystoid Limestone, Katian (Kralodvorian of the Mediterranean regional chronostratigraphic chart), Iberian Chains, Aragon, Spain.

Radnoria dolicocephala (Ji, 1986); Harpidella (s.1.) dolicocephala; Pagoda Formation, uppermost Sandbian to lower Katian (Chen et al. 2011), China; Sheng \& Ji (1987) stated that the type locality is Qijiang, at that time in Sichuan but now in Chongqing Province.

Radnoria elongata Sun, 1990; Rainbow Hill Marl Member, basal Rosebank Shale, Ludfordian, Ludlow, New South Wales, Australia.

Radnoria humillima (Barrande, 1852); Cyphaspis humillima; Liteň Formation, Wenlock, Czech Republic.

Radnoria loredensis (Thadeu, 1947); Proetus loredensis; Leira Má Member, Porto de Santa Ana Formation, Katian (upper Berounian/Kralodvorian? of the Mediterranean regional chronostratigraphic chart), Buçaco, Portugal.

Radnoria simplex (Kolobova, 1978); Otarion simplex; Obikalon Member, Shakhriomon Formation, upper Katian (Armoricochitina nigerica Biozone, Leonid Popov, pers. comm. 2015), Zeravshan Mountains, Uzbekistan. Also identified by Hammann \& Leone (1997) in the Portixeddu Formation, Katian (upper Berounian?/Kralodvorian), Sardinia.

Radnoria triquetra Owens \& Thomas, 1975; Much Wenlock Limestone Formation (Cyrtograptus lundgreni Zone), Wenlock, West Midlands, England.

Other references to Radnoria. - Holloway (1980, p. 28, pl. 5, figs 23, 24) assigned to Radnoria sp. a cranidium from the St Clair Limestone Formation, Sheinwoodian of Arkansas. Owens \& Hammann (1990, pp. 228-229) assigned to Radnoria Apollonov's (1980, pp. 93-94, pl. 25, figs 5, 11) "Brachymetopidae gen." from the Katian of Alma-Ata (Kazakhstan), possibly Dean's (1971, p. 71, pl. 6, fig. 9), Otarion sp. from the Darriwilian of Newfoundland (Canada) and a cranidium from Trenton Falls, New York. We agree with Owens \& Hammann (1990) that there is not enough information on the Otarion sp. specimen from the Darriwilian of Canada to assign it unequivocally to Radnoria. Adrain \& Tetreault (2005, p. 2089) assigned to Radnoria some librigenae from the Wenlock of Arctic Canada that they described as Radnoria sp. 1, R. sp. 2 and $R$. sp. 3. Sandford \& Holloway (2006) identified Radnoria sp. in the Chintin Formation, Telychian of central Victoria (Australia). Ghobadi Pour \& Popov (2009) reported Radnoria simplex in the upper part of the Shirgesht Formation (Darriwilian, Middle Ordovician) of Iran, but did not figure or describe the specimens.

Remarks. - Radnoria is the earliest known brachymetopid trilobite. However, Strasburgaspis Adrain, 2005 from the Edinburg Formation (late Sandbian/early Katian) of Virgi- nia, shows several features, especially in the cephalon and hypostome, indicating a close relationship to Brachymetopidae, and it could represent a basal brachymetopid (Jonathan Adrain, pers. comm. 2014). Owens \& Hammann (1990) assigned the Middle Ordovician Oenonella Fortey, 1980 to the Brachymetopidae, based on perceived shared synapomorphies with Radnoria, but Jell \& Adrain (2003) regarded Oenonella as of uncertain family affinity. Adrain \& Tetreault (2005) tentatively assigned Harpidella (Harpidella) dolianovensis Hammann \& Leone, 1997 from the Katian of Sardinia to Radnoria. However, H. (H.) dolianovensis differs from the other species assigned to Radnoria in the configuration of the preglabellar area and the lack of a very broad cephalic doublure, and on the basis of these features we retain the species in the Aulacopleuridae. Adrain \& Tetreault (2005) questioned the generic assignment of Radnoria elongata from the Ludlow of Australia because of its pygidial features (large number of axial rings and distinct marginal rim) and perceived differences in the cephalon (isolated L1 and broader glabella). However, the type-species $R$. syrphetodes and $R$. humillima from the Wenlock of the Czech Republic have a similar number of pygidial axial rings (10-12) and we do not think that the existence of a marginal rim is a reliable difference (compare Sun 1990, pl. 1, fig. 16 and Fig. 3F herein). An almost completely isolated L1 like that of $R$. elongata is also present in Radnoria guyi sp. nov. and in R. cf. simplex from the Portixeddu Formation of Sardinia (Hammann \& Leone 1997, pl. 22, fig. 2). We do not agree with Adrain \& Tetreault (2005) that $R$. elongata could be an early member of Cordania, because it lacks the typically pronounced epiborder furrow and the anterior facial suture is significantly less divergent.

Proscharyia Peng, 1990 was named as a brachymetopid by Zhou \& Zhou (2008) and Zhou et al. (2011) but the authors did not justify this claim. Lieberman \& Karim (2010) considered Proscharyia to be a separate phylogenetic branch of the Order Aulacopleurida, though directly related to the Scharyiidae and Brachymetopidae, a view previously discussed by Adrain \& Chatterton (1993). Zhou \& Zhou (2008) considered Radnoria to be a junior synonym of Niuchangella Zhang, 1974. It is difficult to assess this view on the basis of the only illustrated specimen of the type species, N. meitanensis Zhang (1974, pl. 80, fig. 11) from the uppermost Hirnantian/lower Rhuddanian of Meitan, northern Guizhou, China; however, Adrain \& Chatterton (1993) and Adrain (2013) assigned Niuchangella to the Scharyiidae and, based on the sub-triangular glabellar outline, laterally displaced L1 and the possibly lower number of thoracic segments (probably eight, not nine as stated by Zhang 1974), we agree with this assignment.

Although the Brachymetopidae was of low generic diversity until the end of the Silurian, the group diversified 
during the Devonian and survived until the end of the Permian, making its study and the understanding of its phylogeny an interesting and important subject for research.

Occurrence. - Ordovician (upper Sandbian?/lower Katian) to Silurian (Ludlow). Ordovician of Iberian Peninsula, Sardinia, Kazakhstan, Uzbekistan and South China; Silurian of Bohemia, United Kingdom, Australia, Canada and United States of America.

\section{Radnoria guyi sp. nov.}

Figure 3

2014 Radnoria aff. simplex; Pereira et al., p. 46, fig. 1.

Etymology. - After Mr Pierre-Marie Guy (Clarensac, France), who found and provided us with the first specimen of this trilobite, making it available for study.

Holotype. - Internal and external moulds of a nearly complete dorsal exoskeleton (MGUTAD 15050a and 15050b, Fig. 3A-E, G).

Type locality and horizon. - Queixopêrra Member, Cabeço do Peão Formation, middle Berounian (Sa2-Ka1 stage slice); outcrop located on the road from Mação to Aboboreira, geographical coordinates $39^{\circ} 34^{\prime} 58.43^{\prime \prime} \mathrm{N}$, $8^{\circ} 1^{\prime} 34.26^{\prime \prime} \mathrm{W}$. Crozonaspis dujardini-Deanaspis seunesi Biozone defined for the southwestern European region (Gutiérrez-Marco et al. 2002).

Paratypes. - Two nearly complete dorsal exoskeletons, one preserved as an internal mould (CMP 0120, Fig. 3H-I) and the other as counterpart moulds (CMP 0122-1a, Fig. 3J right, and 0122-1b); internal and external moulds of a cephalon with part of thorax (CMP 0122-2a and 0122-2b, Fig. 3J left); internal and external moulds of a cephalon and pygidium, possibly of the same individual (CMP 0123a and 0123b, Fig. 3F); an external mould of a cephalon (CMP 0121, not figured); all from the type locality. The material is housed in the Museu Geológico Fernando Real, Universidade de Trás-os-Montes e Alto Douro, Portugal (MGUTAD) and in the Departamento de Geologia, Faculdade de Ciências da Universidade de Lisboa, Portugal (CMP).

Diagnosis. - Radnoria with anterior and posterior branches of facial suture diverging at about $60^{\circ}$ and $45^{\circ}$ respectively to the sagittal line; length of palpebral lobes about one third of the sagittal length of the glabella; glabella and genal field with strong reticulate sculpture of fine ridges; pygidium with eight axial rings and a terminal piece; axial rings bearing prominent median tubercles; axis occupying about $75 \%$ sagittal length of pygidium; pleural region with six backwardly curved pleural furrows.

Description. - Exoskeleton micropygous. Cephalon horseshoe-shaped, with maximum width opposite posterior border $200 \%$ sagittal length. Glabella sub-oval to slightly bell-shaped, strongly vaulted, frontally sloping forwards. Axial furrows deep and narrow, becoming deeper anterior to S2 and shallower anteriorly (preglabellar furrow). Maximum glabellar width across L1 $25 \%$ of maximum cephalic width. Occipital furrow deep medially, shallower and curving backwards slightly at intersection with S1, very deep abaxially where it contains an apodemal pit. Occipital ring slightly wider (sag.) medially, with distal ends curving forwards (adjusting to L1). S1 deep except at intersection with occipital furrow; nearly straight, directed at about $35^{\circ}$ to an exsagittal line. L1 subtriangular, comprising about one-quarter glabellar width, gently inflated. S2 shallow, very narrow (tr.), indistinct. Palpebral lobes almost as high as glabella, with subcircular margin; posterior edge lying more or less opposite occipital furrow and anterior edge lying posterior to S2. Preglabellar field short (sag.). Librigena subtriangular in outline, declined abaxially and extended into a long, wide, subtriangular and pointed genal spine, apparently extending as far back as the pygidium. Lateral border wide. A rim-like, relatively broad (tr.) border roll runs around anterior and lateral cephalic margins from tips of genal spines, bounded on the inside by a deep and narrow epiborder furrow. Fixigenal and librigenal fields with reticulate sculpture as on glabella. Doublure occupies about $35 \%$ of the width of the librigena opposite palpebral lobes; with sculpture of fine, subparallel terrace ridges.

Rostral plate roughly trapezoidal, length (sag.) about $40 \%$ maximum width across rostral suture, connective sutures converging posteriorly and slightly diverging towards inner edge of doublure.

Thorax composed of nine segments. The division between thorax and pygidium is indistinct. Axis strongly arched (tr.), of approximately uniform width on first three segments, thereafter narrowing backwards, width on last segment approximately $60 \%$ of that on first. Axial furrows moderately deep. Axial rings convex (sag.), curving slightly forwards medially and laterally (especially on first few segments). Articulating furrows deep. Pleurae gently downturned at fulcrum, situated more than half way from axial furrow to pleural tip. Pleural furrows deep for most of their length subparallel to anterior and posterior pleural margins.

Pygidium subelliptical, moderately arched (tr. and sag.), with sagittal length about $60 \%$ of maximum width; axis occupying about $75 \%$ sagittal length of pygidium and maximum anterior width about $30 \%$ the maximum pygidial width. Axis with eight convex (sag., tr.) axial rings 
and a rounded terminal piece; axial rings with prominent median tubercles. Inter-ring furrows deep, almost transverse. Axial furrow almost straight, moderately deep, becoming shallower and indistinct posterior to axis. Pleural region gently arched, sloping slightly outwards, with six backwardly curved pleural furrows, the last few becoming shallower. Pleural furrows wider (exsag.) than interpleural furrows, especially distally where pleural furrows become diffuse. Posterior pleural bands expand slightly abaxially and are more elevated than anterior bands distally. Pygidial doublure extending forwards medially to axial termination. Doublure bears regular, fine and closely spaced terrace lines (closer than those on librigenal doublure) running parallel to pygidial margin.

Remarks. - The cephalic morphology of the species, with its very broad doublure, long, broad-based genal spines and glabella with small, distinct L1 all support assignment to Radnoria. The presence of the distinctive strong reticulate sculpture on the glabella and genal fields readily distinguish it from other species assigned to the genus.

Among Ordovician representatives of Radnoria, $R$. guyi is most similar to R. simplex (Kolobova, 1978, pp. 129-130, pl. 24, figs 10-13), from the lower-mid Sandbian of Uzbekistan. However, besides the distinctive sculpture mentioned above, the palpebral lobe in Radnoria guyi is smaller and does not extend as far forward, and L1 is relatively larger. Further comparisons between these species are difficult due to their relatively poor preservation.

Hammann \& Leone (1997, pp. 107-110, pl. 21, figs 1-8) identified $R$. simplex in the middle part of the Portixeddu Formation (Kralodvorian) of Sardinia. The cephala figured differ from $R$. guyi in the same features as the specimens of $R$. simplex from Uzbekistan. The pygidia illustrated by Hammann \& Leone appear to be similar to that of $R$. guyi but the axis seems more parallel-sided, the axial rings lack median tubercles and the terminal piece of the axis is not as well defined. These differences do not seem to be related to preservation. We consider that Hammann \& Leone's specimens are closer to $R$. loredensis (see below) than to the types of $R$. simplex, but additional and better material of $R$. loredensis is needed to assess whether the Sardinian specimens might be conspecific. Hammann \& Leone (1997, pl. 22, figs 1-5) also documented specimens they named $R$. cf. simplex from the lower part of the Portixeddu Formation, suggesting that their stronger caecal sculpture and larger L1 compared to the specimens from higher in the formation are probably the result of deformation. We agree with Adrain \& Tetreault (2005) that these and other morphological differences indicate the presence of two distinct species of Radnoria in the Portixeddu Formation. However, a complete specimen collected by us at locality Gon 1 of Hammann \& Leone (horizon TH2b, the lower part of the Portixeddu Formation) suggests that the two species are not separated stratigraphically but occur together, at least in the lower part of the formation. This specimen also shows that $R$. simplex from Sardinia has nine thoracic segments, not 10 as suggested by Hammann \& Leone, though they did not have any complete articulated specimens. Radnoria may have maintained nine thoracic segments throughout its evolutionary history. $R$. cf. simplex of Hammann \& Leone is similar to Radnoria guyi in having a large L1 and relatively small palpebral lobes, but differs in the other cephalic features already mentioned, as well as in having a more elongated pygidium with one or two additional axial rings.

Radnoria carlsi Owens \& Hammann (1990, pp. 226-228, figs 2-5) from the Kralodvorian of Spain, also figured by Hammann (1992, p. 92, pl. 20, figs 1-8), differs from $R$. guyi in having a smaller and narrower glabella, deeper cephalic axial furrows and less divergent anterior branches of the facial suture. The anterior and posterior pleural bands of the pygidium are more elevated abaxially and the postaxial region is much longer.

Radnoria dolichocephala (Ji, 1986, p. 18, pl. 4, figs 7-11) from the Pagoda Formation (upper Sandbian?/lower Katian of China), although poorly preserved, appears to have a smaller and more elongated glabella than R. guyi, L1 is smaller and more depressed, the pygidium has nine rather than seven axial rings and there are rows of tubercles on the posterior pleural bands.

Radnoria loredensis (Thadeu, 1947, p. 226, pl. 2, figs 11-13) from the upper Berounian/Kralodvorian? of Portugal differs from $R$. guyi in having larger, more forwardly placed palpebral lobes, a smaller L1 and a pygidium with wider and more elevated pleural ribs and shallower, almost imperceptible pleural furrows.

Silurian representatives of Radnoria have pygidia with a greater number of both axial rings and pleural ribs than $R$. guyi and lack strong sculpture on the glabella. The type species $R$. syrphetodes from the Wenlock of Wales also has larger eyes that are more anteriorly located and lacks median

Figure 3. Radnoria guyi sp. nov. from the Queixopêrra Member of the Cabeço do Peão Formation, Middle Berounian (Upper Ordovician, approximately Sa2/Ka1), Mação, Portugal. • A, C, G - MGUTAD15050a, internal mould with external mould of cephalic doublure; A - dorsal view; C- oblique view; G - detail of pygidium. - B, D, E - MGUTAD15050b, counterpart external mould; B - latex cast, dorsal view; D - detail of glabellar sculpture; E - latex cast showing detail of glabellar sculpture. $\bullet \mathrm{F}-\mathrm{CMP} 0123 \mathrm{~b}$, external mould, dorsal view. $\bullet \mathrm{H}$, I - CMP0120, internal mould; H - oblique view; I - dorsal view. $• J$ - CMP0122-1a, internal mould with external mould of cephalic doublure (right), and CMP0122-2b, external mould (left), dorsal view. Scale bars represent $2 \mathrm{~mm}$. 

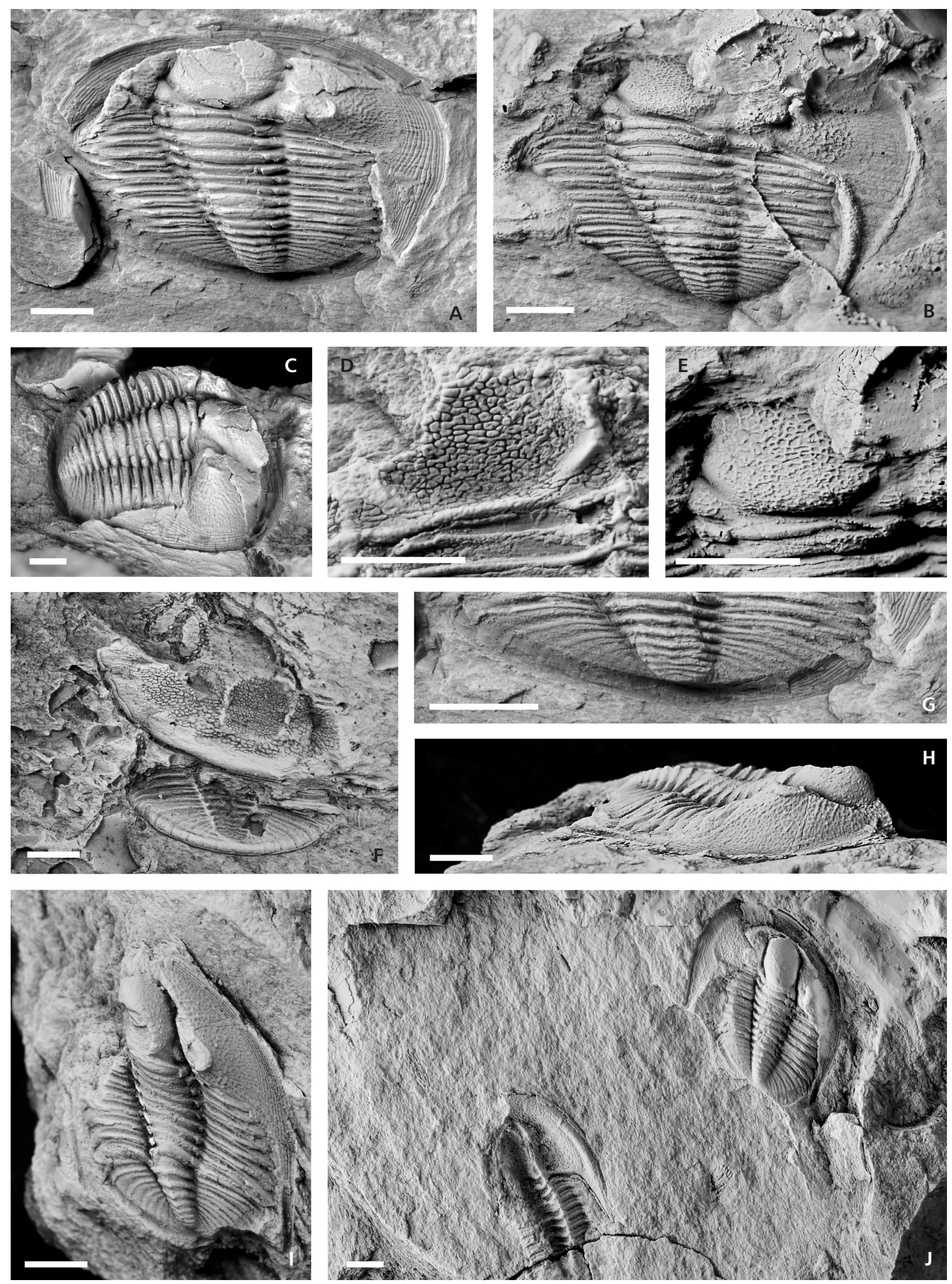


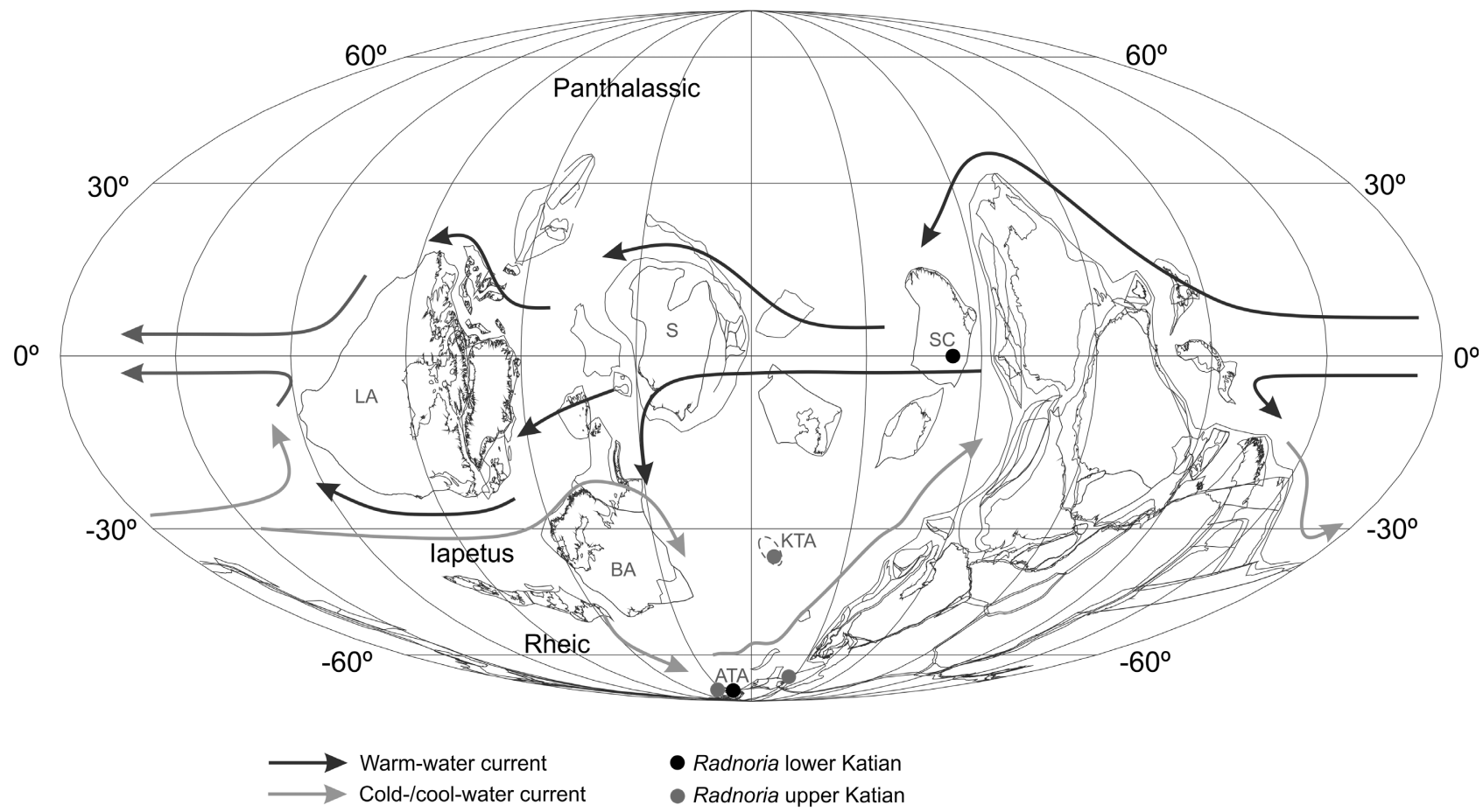

Figure 4. Mollweide palaeogeographic reconstruction for the Sandbian/Katian limit (453 Ma), showing the known occurrences of Radnoria of Katian age. Palaeocurrents shown are based on the literature (see text for references). Abbreviations: ATA - Armorica Terranes Assemblage; BA - Baltica; KTA - Kazakh Terranes Assemblage; LA - Laurentia; S - Siberia; SC - South-China. Mollweide projection provided by Trond Torsvik's BugPlates software (2011). Kazakh Terranes Assemblage based on Torsvik \& Cocks (2013).

tubercles on the pygidial axial rings. Radnoria bretti Adrain \& Tetreault (2005, figs 2-4) has a shallower, more oblique $\mathrm{S} 1$ and shallower interpleural furrows in the pygidium. Radnoria triquetra Owens \& Thomas (1975, pp. 816-817, pl. 96, figs 3-5) has a conical glabella, deeper cephalic axial furrows, the anterior sections of the facial suture are less divergent and the pygidia have tubercles not only on the axial rings as in $R$. guyi but also on the posterior pleural bands. Radnoria humillima (Barrande 1852, pl. 18, figs 57, 58) from Bohemia differs from $R$. guyi in having 12 axial rings.

\section{Biogeographical remarks}

Radnoria guyi together with $R$. dolicocephala from China are the oldest known species of Radnoria, both of them from the upper Sandbian/lower Katian. It is not possible to determine the chronostratigraphic position of the Chinese species more precisely, as Ji (1986) did not indicate its stratigraphical range within the Pagoda Formation. Sheng \& Ji (1986) indicated, however, that $R$. dolicocephala occurs in the middle and upper parts of the formation. Radnoria guyi and $R$. dolicocephala are also the oldest known definite brachymetopids, but if it is shown in the future that Strasburgaspis (Sandbian, Virginia, USA) is a basal brachymetopid, then the stratigraphic range of the family will be extended downwards.
Global Ordovician palaeogeography and the various oceanic palaeocirculation models published for this period (Wilde 1991, Christiansen \& Stouge 1999, Herrmann et al. 2004, Rasmussen 2011) suggest that faunal exchanges along the North Gondwanan margin were likely influenced by a well-developed SW-NE oceanic current (Fig. 4), the cool-water current that ran along the western-facing margins of Gondwana (Gutiérrez-Marco \& Rábano 1987). This would allow trilobites of the Dalmanitoidean Realm (sensu Adrain et al. 2004) from the high-latitude Gondwana region to reach South China via peri-Gondwana terranes such as the Pontides, the Taurides and the Kazakh terranes (e.g. Neseuretus, Prionocheilus and probably Cekovia). This pattern of distribution is also observed in other groups, such as brachiopods (e.g. Rasmussen 2011, Harper et al. 2013).

The short-lived episode of global warming during the late Katian, the Boda event (Fortey \& Cocks 2005), allowed several Laurentian trilobite taxa (e.g. Holdenia and Heliomeroides) to extend their geographical distribution to higher latitude regions. Some taxa of South China and/or Kazakhstan also appear in the high-latitude Gondwanan region at this time (e.g. Paraphillipsinella and Taklamakania). This "poleward invasion" (sensu Fortey \& Cocks 2005) became evident by the middle to late Katian, with alterations to the typical Sandbian and early Katian distribution patterns. However, Radnoria guyi and R. do- 
lichocephala are older than the Boda event and the associated faunal migrations.

Hammann (1992, table 2) analysed the stratigraphical and palaeogeographical distribution of some Ordovician trilobite genera, and distinguished groups of different origin: North-Gondwana, Avalonia, Baltica, Laurentia, Kazakhstania and North/South China. He proposed a probable Laurentian origin for Radnoria, although the oldest records of the genus known at that time were from Uzbekistan and South China. Other genera with this distribution (e.g. Ovalocephalus and Sinocybele) were proposed to have originated from South China.

Based on the oldest records of Radnoria known to date (approximately late Sandbian/early Katian of the Armorica Terrane Assemblage and South China), we suggest that dispersal of the genus was probably influenced by the cool-water current that controlled the expansion of other taxa along the western edge of Gondwana (Fig. 4), from the high-latitude Gondwanan region to South China. Based on the available occurrences, it is more likely that Radnoria originated from the high-latitude Gondwanan region, where it has several Katian records (four of the five named Ordovician species), and not from Laurentia as proposed by Hammann (1992).

\section{Conclusions}

The occurrence of Radnoria in the middle Berounian (approximately upper Sandbian/lower Katian) of Portugal sheds new light on our understanding of the biogeography of this genus, suggesting that it had a high-latitude Gondwanan origin. Radnoria guyi is the earliest known occurrence of this genus in the European peri-Gondwana and the best preserved and most completely known of the Ordovician species. Our study also draws attention to the fact that a revision of Ordovician-Silurian representatives of the Brachymetopidae, which are clearly undersampled and grouped together in the single genus Radnoria, is of paramount importance. Future studies on better-preserved specimens and more representatives of this family will provide new data to clarify the origins of Radnoria.

\section{Acknowledgements}

We are indebted to S. Sheffield (University of Tennessee) for English improvement of the manuscript and help in the fieldwork in Sardinia (Italy). We thank S. Zamora (Instituto Geológico y Minero de España) and J. Colmenar (Universidad de Zaragoza) for help in the fieldwork in Sardinia; M. Ramalho (Museu Geológico de Lisboa) and J. Ignacio (Universidad de Zaragoza) for access to fossil collections; J.-C. Gutiérrez-Marco (CSIC-Spanish National Research Council) for facilitating access to P.-M. Guy's specimen; J. Adrain (University of Iowa) for help- ful discussion; and J. Esteve (University of West Bohemia) for comments. We thank R.M. Owens (National Museum of Wales) and D.L. Bruton (Natural History Museum, University of Oslo) for reviewing this paper. We specially thank D. Holloway (Museum Victoria) for valuable revisions, discussion and suggestions that allowed us to improve our manuscript significantly. SP is supported by a FCT PhD grant (SFRH/BD/73722/2010). This research received support from the SYNTHESYS Project (http://www.synthesys.info/) which is financed by European CommunityResearch Infrastructure Action under the FP7 "Capacities" Program. AAS is supported by the project CGL2012-39471 of the MINECO. This paper is a contribution to the International Geoscience Programme (IGCP) Project 591 The Early to Middle Paleozoic Revolution (IUGS-UNESCO).

\section{References}

Adrain, J.M. 2005. Aulacopleurid trilobites from the Upper Ordovician of Virginia. Journal of Paleontology 79, 542-563. DOI 10.1666/0022-3360(2005)079<0542:ATFTUO >2.0.CO;2

Adrain, J.M. 2011. Class Trilobita Walch, 1771, 104-109. In Zhang, Z.Q. (ed.) Animal biodiversity: an outline of higher level classification and survey of taxonomic richness. Zootaxa 3148.

AdRaIn, J.M. 2013. A synopsis of Ordovician trilobite distribution and diversity, 297-336. In HARPER, D.A.T. \& SERVAIs, T. (eds) Early Palaeozoic palaeobiogeography and palaeogeography. Geological Society of London, Memoir 38.

Adrain, J.M. \& Chatterton, B.D.E. 1993. A new rorringtoniid trilobite from the Ludlow of Artic Canada. Canadian Journal of Earth Sciences 30, 1634-1643.

Adrain, J.M., Edgecombe, G.D., Fortey, R.A., Hammer, Ø., Laurie, J.R., McCormick, T., Owen, A.W., Waisfeld, B.G., Webby, B.D., Westrop, S.R. \& Zhou, Z.Y. 2004. Trilobites, 231-254. In Webby, B.D., Paris, F., Droser, M.L. \& PerCIVAL, I.G. (eds) The Great Ordovician Biodiversification Event. Columbia University Press, New York.

Adrain, J.M. \& Tetreault, D.K. 2005. The brachymetopid trilobite Radnoria in the Silurian (Wenlock) of New York State and Arctic Canada. Canadian Journal of Earth Sciences 42, 2087-2096. DOI 10.1139/e05-085

Apollonov, M.K. 1980. Klass Trilobita. Trilobity, 86-118. In Apollonov, M.K., Bandaletov, S.M. \& Nikitin, I.F. (eds) Granitsa ordovika i silura v Kazachstane. Nauka, Alma Ata.

BARRANDE, J. 1852. Systême silurien du centre de la Bohême. Ière Partie. Recherches paléontologiques. 1. Crustacés: Trilobites. 935 pp. Published by the author, Prague \& Paris.

BRUTON, D.L. 2008. A systematic revision of Selenopeltis (Trilobita: Odontopleuridae) with description of new material from the Ordovician Anti-Atlas region, Morocco. Paläontologische Zeitschrift 82(1), 1-16. DOI 10.1007/BF02988429

CarlucCI, J.R. \& Westrop, S.R. 2012. Trilobite biofacies along an Ordovician (Sandbian) carbonate buildup to basin gradient, southwestern Virginia. Palaios 27, 19-34.

DOI 10.2110/palo.2011.p11-069r

Chen, X., Bergström, S.M., Zhang, Y., Goldman, D. \& Chen, Q. 2011. Upper Ordovician (Sandbian-Katian) graptolite and 
conodont zonation in the Yangtze region, China. Earth and Environmental Science Transactions of the Royal Society of Edinburgh 101, 111-134.

Christiansen, J.L. \& Stouge, S. 1999. Oceanic circulation as an element in palaeogeographical reconstructions: the Arenig (early Ordovician) as an example. Terra Nova 11, 73-78. DOI 10.1046/j.1365-3121.1999.00229.x

Conti, S. \& Serpagli, E. 1988. Bimineralic (calcareous and phosphatic) skeleton in Late Ordovician bryozoan from Sardinia: geological implications. Bollettino della Società Paleontologica Italiana 27, 129-162.

COOPER, A.H. 1980. The stratigraphy and palaeontology of the Ordovician to Devonian rocks of the area north of Dornes (near Figueiró dos Vinhos), central Portugal. 378 pp. PhD thesis, University of Sheffield, Sheffield, United Kingdom.

DeAn, W.T. 1971. Ordovician trilobites from the central volcanic mobile belt at New World Island, northeastern Newfoundland. Bulletin of the Geological Survey of Canada 210, 1-37.

Delgado, J.F.N. 1908. Système silurique du Portugal. Étude de stratigraphie paléontologique. $245 \mathrm{pp}$. Memórias da Commissão dos Serviços geologicos de Portugal, Lisbon.

ForTEy, R.A. 1975. Early Ordovician trilobite communities. Fossils and Strata 4, 331-352.

FORTEY, R.A. 1980. The Ordovician trilobites of Spitsbergen. III. Remaining trilobites of the Valhallfonna Formation. Norsk Polarinstitutt Skrifter 171, 1-163.

ForTEY, R.A. \& CoCKs, L.R.M. 2003. Palaeontological evidence bearing on global Ordovician-Silurian continental reconstructions. Earth Science Reviews 61, 245-307. DOI 10.1016/S0012-8252(02)00115-0

ForTEY, R.A. \& Cocks, L.R.M. 2005. Late Ordovician global warming: the Boda event. Geology 33(5), 405-408. DOI $10.1130 / \mathrm{G} 21180.1$

Ghobadi Pour, M. \& Popov, L.E. 2009. First report on the occurrence of Neseuretinus and Ovalocephalus trilobites in the Middle Ordovician of Iran. Acta Palaentologica Polonica 54, 125-133. DOI 10.4202/app.2009.0113

Gutiérrez-Marco, J.-C. \& RÁbano, I. 1987. Paleobiogeographical aspects of the Ordovician Mediterranean faunas. Geogaceta 2, 24-26.

Gutiérrez-Marco, J.-C., Robardet, M., RÁbano, I., Sarmiento, G.N., San José, M.A., Herranz Araújo, P. \& Pieren Pidal, A.P. 2002. Ordovician, 31-47. In GibBons, W. \& Moreno, M.T. (eds) The Geology of Spain. Geological Society of London, London.

Guy, P.-M. \& Lebrun, P. 2010. Les trilobites de l'Ordovicien du Portugal. Fossiles, hors-serie 1, 41-88.

HammanN, W. 1992. The Ordovician trilobites from the Iberian Chains in the Province of Aragón, NE Spain. I. The trilobites of the Cystoid Limestone (Ashgill Series). Beringeria 6, $1-219$.

Hammann, W. \& Leone, F. 1997. Trilobites of the post-Sardic (Upper Ordovician) sequence of southern Sardinia. Part I. Beringeria 20, 3-217.

Harper, D.A.T., Rasmussen, C.M.O., Liljeroth, M., Blodgett, R.B., Candela, Y., Jin, J., Percival, I.G., Rong, J.Y., Villas, E. \& ZhAN, R.B. 2013. Biodiversity, biogeography and phylogeography of Ordovician rhynchonelliform brachiopods, 127-144. In Harper, D.A.T. \& Servais, T. (eds) Early
Palaeozoic biogeography and palaeogeography. Geological Society of London Memoir 38.

Herrmann, A.D., Haupt, B.J., Patzkowsky, M.E., Seidov, D. \& SLingerland, R.L. 2004. Response of Late Ordovician paleoceanography to changes in sea level, continental drift, and atmospheric $p \mathrm{CO}_{2}$ : potential causes for long-term cooling and glaciation. Palaeogeography, Palaeoclimatology, Palaeoecology 210, 385-401.

DOI 10.1016/j.palaeo.2004.02.034

Holloway, D.J. 1980. Middle Silurian trilobites from Arkansas and Oklahoma, USA. Part 1. Palaeontographica, Abteilung A $170,1-85$.

Jell, P.A. \& Adrain, J.M. 2003. Available generic names for trilobites. Memoirs of the Queensland Museum 48, 331-553.

JI, Z. 1986. Upper Ordovician (middle Caradoc-early Ashgill) trilobites from the Pagoda Formation in South China. Professional Papers of Stratigraphy and Palaeontology 15, 1-39. [in Chinese]

Kolobova, I.M. 1978. Klass Trilobita, 126-144. In Sokolov, B.S. \& Yolkin, E.A. (eds) Pogranichnye sloi ordovika i silura Altae-Saianskoi oblasti $i$ Tyan-Shanya. Trudy Instituta geologii i geofiziki, Sibirskoe otdelenie, Akademiya nauk SSSR 397.

Le Corre, C., Auvray, B., Ballèvre, M. \& Robardet, M. 1991. Le Massif Armoricain. Scientific Geological Bulletin 44(1-2), 31-103.

Leone, F., Hammann, W., Laske, R., Serpagli, E. \& Villas, E. 1991. Lithostratigraphic units and biostratigraphy of the post-Sardic Ordovician sequence in south-west Sardinia. Bollettino della Società Paleontologica Italiana 30(2), 201-235.

Lieberman, B.S. \& Karim, T.S. 2010. Tracing the trilobite tree from the root to the tips: a model marriage of fossils and phylogeny. Arthropod Structure \& Development 39, 111-123. DOI 10.1016/j.asd.2009.10.004

Metodiev, D. \& Romão, J. 2008. Novos dados sobre a estrutura em sinclinal complexo de Vila Velha de Rodão (bordo SW da Zona Centro-Ibérica). Memórias do Departamento de Geologia da Faculdade de Ciências da Universidade do Porto $13,30-34$.

Metodiev, D., Romão, J., Dias, R. \& Ribeiro, A. 2010. Sinclinal Varisco de Serra do Moradal-Fajão (Zona Centro-Ibérica, Portugal Central): padrões estratigráficos e estruturais. E-Terra 11(19), 1-4. http://metododirecto.pt/CNG2010/index.php/ vol/article/view/129/253.

Mikulic, D.G. 1981. Trilobites in Palaeozoic carbonate buildups. Lethaia 14, 45-56. DOI 10.1111/j.1502-3931.1981.tb01073.x

Owens, R.M. \& Hammann, W. 1990. Proetide trilobites from the Cystoid Limestone (Ashgill) of NW Spain, and the suprageneric classification of related forms. Paläontologische Zeitschrift 64(3/4), 221-244. DOI 10.1007/BF02985716

Owens, R.M. \& Thomas, A.T. 1975. Radnoria, a new Silurian proetacean trilobite, and the origins of the Brachymetopidae. Palaeontology 18, 809-822.

PENG, S.C. 1990. Tremadoc stratigraphy and trilobite faunas of northwestern Hunan. 2. Trilobites from the Panjiazui Formation and the Madaoyu Formation in Jiangnan Slope Belt. Beringeria 2, 55-171. 
Pereira, S., Sá, A.A. \& Marques da Silva, C. 2014. The oldest brachymetopid trilobite record from the Mediterranean region. New Insights on Ancient Life, XII Encuentro de Jóvenes Investigadores en Paleontología, Sobrarbe, 43-46.

Pereira, S., Sá, A.A., Marques da Silva, C. \& Vaz, N. in press. Panderia beaumonti (Rouault, 1847) da Formação Cabeço do Peão do Katiano inferior (Ordovícico Superior, Portugal). Comunicaçóes Geológicas.

Piçarra, J.M., Romão, J., Gutiérrez-Marco, J.-C. \& Oliveira, J.T. 1999. Preliminary note on the Ordovician-Silurian stratigraphic sequence of the Serra de São Mamede region, southern border of the Central-Iberian Zone, Portugal. Journal of Conference Abstracts 4(3), 1018.

Prantl, F. \& PřIBYL, A. 1951. A revision of the Bohemian representatives of the Family Otarionidae R. \& E. Richter (Trilobitae). Sborník Státního geologického ústavu Československé republiky, Oddíl paleontologický 17, 353-512.

RASMUSSEN, C.M.Ø. 2011. Final destination, first discovered: the tale of Oanduporella Hints, 1975, 447-454. In GuTIÉRREZMarco, J.-C., RÁbano, I. \& García-Bellido, D. (eds) Ordovician of the World, Cuadernos del Museo Geominero 14. Instituto Geológico y Minero de Espańa, Madrid.

Romano, M. 1980. The trilobite Eccoptochile from the Ordovician of northern Portugal. Palaeontology 23, 605-616.

Romano, M. 1982. A revision of the Portuguese Ordovician Odontopleuridae (Trilobita): Selenopeltis and Primaspis. Comunicações dos Serviços Geológicos de Portugal 68(2), 213-223.

Romano, M. 1991. Trilobites from the Ordovician of Portugal. Palaeontology 34, 329-355.

Romano, M. \& Henry, J.-L. 1982. The trilobite genus Eoharpes from the Ordovician of Brittany and Portugal. Palaeontology 25(3), 623-633.

Romão, J.M.C. 2000. Estudo tectono-estratigráfico de um segmento do bordo SW da Zona Centro-Ibérica, e as suas relações com a Zona Ossa Morena. 322 pp. PhD thesis, University of Lisbon, Lisbon, Portugal.

Romão, J.M.C., Gutiérrez-Marco, J.-C., RÁbano, I., Oliveira, J.T. \& Marques Guedes, A. 1995. A Formação Cabeço do Peão (Ordovícico Superior) no sinforma Amêndoa-Carvoeiro (SW da ZCI) e sua correlação estratigráfica na província mediterrânica. Memórias do Museu e Laboratório Mineralógico e Geológico da Faculdade de Ciências da Universidade do Porto 4, 121-126.

SÁ, A.A. 2005. Bioestratigrafia do Ordovícico do nordeste de Portugal. 571 pp. PhD thesis, University of Trás-os-Montes e Alto Douro, Vila Real, Portugal.

Sá, A., Meireles, C., Coke, C. \& Gutiérrez-Marco, J.-C. 2005. Unidades litoestratigráficas do Ordovícico da região de Trás-os-Montes (Zona Centro Ibérica). Comunicações Geológicas 92, 31-74.

Sá, A.A., Piçarra, J., Vaz, N., Sequeira, A. \& GutiérrezMarco, J.-C. 2011. Ordovician of Portugal. 79 pp. $11^{\text {th }}$ Inter- national Symposium on the Ordovician System, Pre-Conference Field Trip Guide.

SANDFORD, A.C. \& Holloway, D.J. 2006. Early Silurian phacopide trilobites from central Victoria, Australia. Memoirs of Museum Victoria 63, 215-255.

Sequeira, A.J.D., Proença Cunha, P. \& Ribeiro, M.L. 1999. Carta Geológica de Portugal na escala de 1:50.000. Notícia explicativa da folha 25-B (Salvaterra do Extremo). 47 pp. Serviços Geológicos de Portugal, Lisboa.

Sheng, X. \& Ji, Z. 1986. On the age of the Pagoda Formation. Professional Papers of Stratigraphy and Palaeontology 16, $1-36$.

Sun, X.W. 1990. Proetacean trilobites from the Ludlow of the Yass Basin, New South Wales (Australia). Geobios 23, 95-109. DOI 10.1016/0016-6995(90)80020-G

Thadeu, D. 1947. Trilobites do Silúrico de Loredo (Buçaco). Boletim da Sociedade Geológica de Portugal 6(3), 217-236.

ToRsvik, T.H. 2011. BugPlates: linking biogeography and palaeogeography. http://www.geodynamics.no/Web/Content /Software/

Torsvik, T.H. \& Cocks, L.R.M. 2013. New global palaeogeographical reconstructions for the Early Palaeozoic and their generation, 5-24. In HARPER, D.A.T. \& SERVAis, T. (eds) Early Palaeozoic biogeography and palaeogeography. Geological Society of London Memoir 38.

VAZ, N. 2010. Palinoestratigrafia da sequência OrdovícicoSilúrica do Sinclinal Amêndoa-Mação. 195 pp. PhD thesis, University of Trás-ots-Montes e Alto Douro, Vila Real, Portugal.

WILDE, P. 1991. Oceanography in the Ordovician, 283-298. In BARNeS, C.R. \& Williams, S.H. (eds) Advances in Ordovician geology. Geological Survey of Canada Paper 90-9.

Young, T.P. 1985. The stratigraphy of the Upper Ordovician of central Portugal. 441 pp. PhD thesis, University of Sheffield, Sheffield, United Kingdom.

YounG, T.P. 1988. The lithostratigraphy of the upper Ordovician of central Portugal. Journal of the Geological Society 145, 377-392. DOI 10.1144/gsjgs.145.3.0377

Zhang, W.T. 1974. [Silurian] Trilobites, 173-187. In NANJING INstitute of Geology and Palaeontology, Academica Sinica (ed.) Handbook of the stratigraphy and palaeontology of southwest China. Science Press, Beijing. [in Chinese]

Zhou, Z.Y., Bergström, J., Zhou, Z.Q., YuAn, W.W. \& Zhang, Y.B. 2011. Trilobite biofacies and palaeogeographic development in the Arenig (Ordovician) of the Yangtze Block, China. Palaeoworld 20, 15-45. DOI 10.1016/j.palwor.2010.12.005

Zноu, Z.Y. \& Zноu, Z.Q. 2008. Chapter 8. Latest Cambrian and Ordovician, 208-274. In ZHou, Z.Y. \& ZHEN, Y.Y. (eds) Trilobite Record of China. Science Press, Beijing.

Zноu, Z.Y., ZноU, Z.Q. \& ZнаNG, J.L. 1989. Ordovician trilobite facies of North China platform and its western marginal area. Acta Palaeontologica Sinica 28, 296-313. [in Chinese with English abstract] 